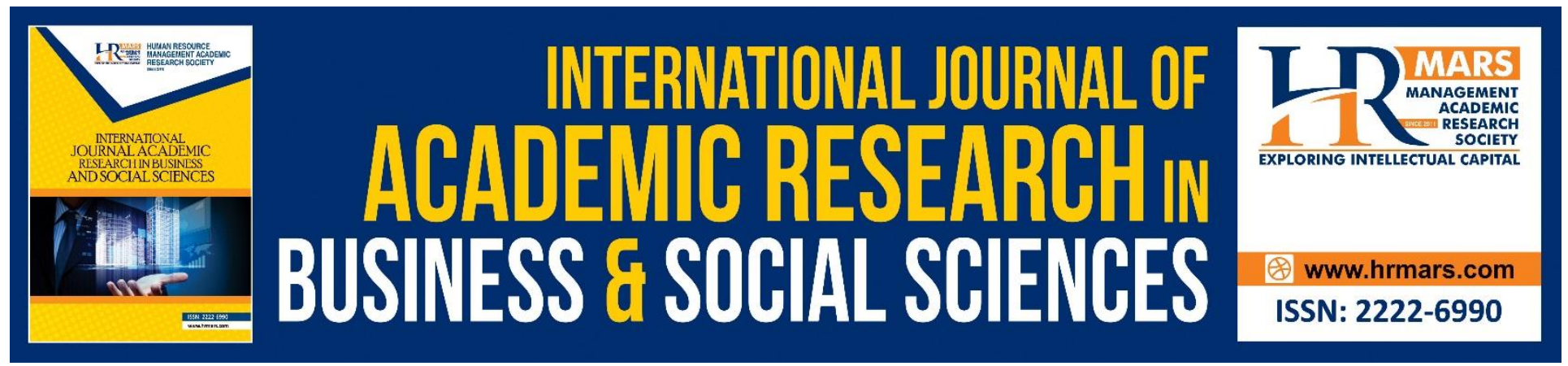

\title{
Weaknesses of Economic Development on Semaq Beri in Terengganu
}

Faizol Subhi, Hafis Simin, Ramle Abdullah, Sahar Sa'di

To Link this Article: http://dx.doi.org/10.6007/IJARBSS/v9-i1/5517

DOI: $\quad 10.6007 /$ IJARBSS/v9-i1/5517

Received: 28 Nov 2018, Revised: 27 Dec 2018, Accepted: 14 Jan 2019

Published Online: 15 Jan 2019

In-Text Citation: (Subhi, Simin, Abdullah, \& Sa'di, 2019)

To Cite this Article: Subhi, F., Simin, H., Abdullah, R., \& Sa'di, S. (2019). Weaknesses of Economic Development on Semaq Beri in Terengganu. International Journal of Academic Research in Business and Social Sciences, 9(1), 1134-1141.

Copyright: (C) 2019 The Author(s)

Published by Human Resource Management Academic Research Society (www.hrmars.com)

This article is published under the Creative Commons Attribution (CC BY 4.0) license. Anyone may reproduce, distribute, translate and create derivative works of this article (for both commercial and non-commercial purposes), subject to full attribution to the original publication and authors. The full terms of this license may be seen

at: $\underline{\text { http://creativecommons.org/licences/by/4.0/legalcode }}$

Vol. 9, No. 1, 2019, Pg. 1134 - 1141

http://hrmars.com/index.php/pages/detail/IJARBSS

JOURNAL HOMEPAGE

Full Terms \& Conditions of access and use can be found at http://hrmars.com/index.php/pages/detail/publication-ethics 


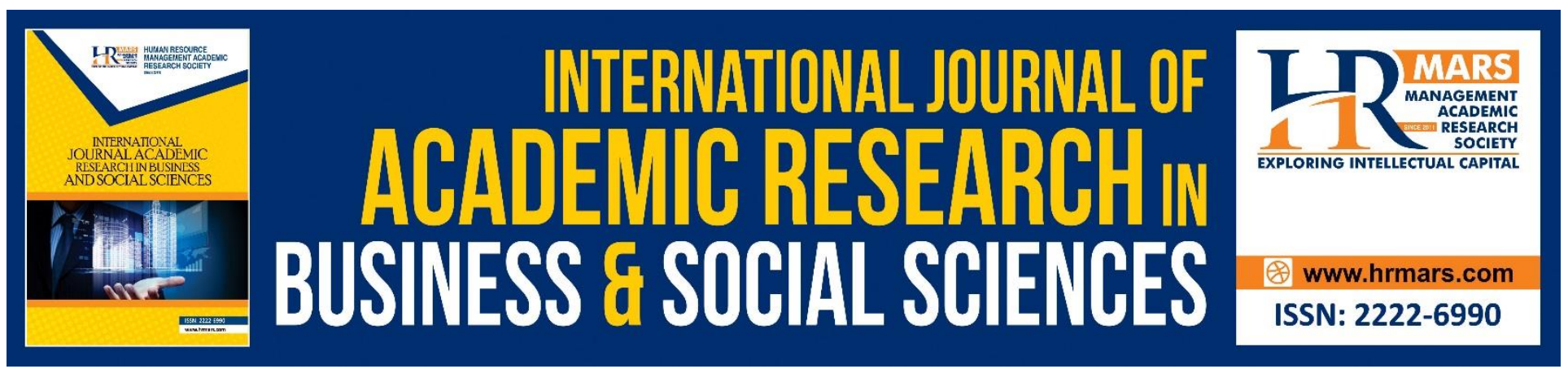

\title{
Weaknesses of Economic Development on Semaq Beri in Terengganu
}

\author{
Faizol Subhi, Hafis Simin, Ramle Abdullah, Sahar Sa'di \\ Faculty of Applied Social Sciences, Sultan Zainal Abidin University, Malaysia
}

\begin{abstract}
After independence the government has embarked on an inclusive development program in an effort to develop the Orang Asli community. Various development projects have been carry out to the Orang Asli community including resettlement of residences, rural road projects, provide of electricity, clean water and social facilities such as education to the Orang Asli. JAKOA has planned and implemented development programs as requested by the government. However, at the level of Orang Asli involvement in the development program it is still low. Limited and low involvement has affected the formation and development of the Orang Asli community. This is why most Orang Asli in Malaysia are still trapped in poverty. Therefore, the study was conducted to find out the factors to the lack of participation among Semaq Beri community at Hulu Terengganu. The results of the study are expected to provide an explanation on why some economic development programs have failed. From the findings, it also helps in planning and implementing more effective economic development programs in the future.
\end{abstract}

Keywords: Orang Asli Development, Economic Development Program, Participation, Problems, Poverty

\section{INTRODUCTION}

In Malaysia, the main challenge faced by the government in developing Orang Asli communities effectively is relate to the poverty problems faced by this community. The poverty problems is believe to be closely link to their economic activities. They are communities that are still depend on the forest by living a self-reliant economy. Most of these economic activities are not viable and cause the average Orang Asli to be poor. Such economic activities also do not guarantee a steady and stable income and earnings for them because of low market prices or cheated by the buyer who control the prices of forest products (JAKOA, 2011; Khairul \& Ibrahim, 2007; Ramle, 2008). The effects of living in poverty are long lasting and recyclable, this can be notice as the next generation will face poverty and setbacks like the previous generation.

From the perspective of poverty, Colin (1998) states that in 1997, 80.8 percent of the Orang Asli's head of household was under the national poverty line. While 49.9 percent of them are categorized 
as hardcore poor. The same situation was still happen in 2003, of which around 86.3 per cent of Orang Asli's head of household were still in poverty (Zainal Abidin, 2004). But in 2010, the poverty rate of the Orang Asli community has dropped below 50 per cent, only 31.16 per cent or 11,423 out of 36,658 Orang Asli's head of household categorized as poor and hardcore poor (JAKOA, 2011).

The problem of poverty is also among the Orang Asli community in the state of Terengganu including the Orang Asli community of Semaq Beri in Kampung Sungai Berua. In the 1980s, the majority of families from this village were categorize as hardcore poor. Their monthly income is estimate at only RM 150.00 (Ramle, 1993). This situation persisted until the 1990's, which is almost 80 per cent of Semaq Beri's head of household in Kampung Sungai Berua earning between RM 200.00 and RM 300.00 per month (Ramle, 2001).

The issue is why the poverty rate remains high among Orang Asli communities in Terengganu, especially in Kampung Sungai Berua whereas the poverty problem among them has received attention since Malaysia achieved independence. Starting from 1960 until now, various development programs and projects have been carry out focusing on economic development, the development of relocation and social development. All programs are based on the targets to advance them and integrate them into the mainstream society (Ramle \& Razak, 2007).

The issue of poverty have been link to their acceptance of development. Hasan (1998) states that there are a handful of Orang Asli who reluctant development. Some of Orang Asli wants to live free from disruption and want to pursue their traditional way of life because it is their will and identity. Thus, government-led development is consider to disrupt their lives. Asnarulkhadi (2005) states that the Orang Asli community is said to be immune to the development of mainstream. They are not interested in development by marginalizing it.

Therefore, researchers are trying to explore in more detail what happens to the Semaq Beri Hulu Terengganu community. Some issues related to the problems that occur in this society will be the focus of the study. Among the issues being focus are the problems faced in the involvement of the economic development program.

\section{METHODOLOGY}

This study was conduct using qualitative methods. According to Lexy (2007) a qualitative method is a research procedure that produces an overview of the data that can be understood. The selection of qualitative methods is consider appropriate for the use of this study as the researcher wants to understand about the Semaq Beri with more depth especially from the aspect of engagement and problem in their involvement. The study was conducted among the Semaq Beri tribes who lived in the settlement of Kampung Sungai Berua, Hulu Terengganu, Terengganu. Figure 1 below shows the location of Kampung Sungai Berua which study was conduct. 


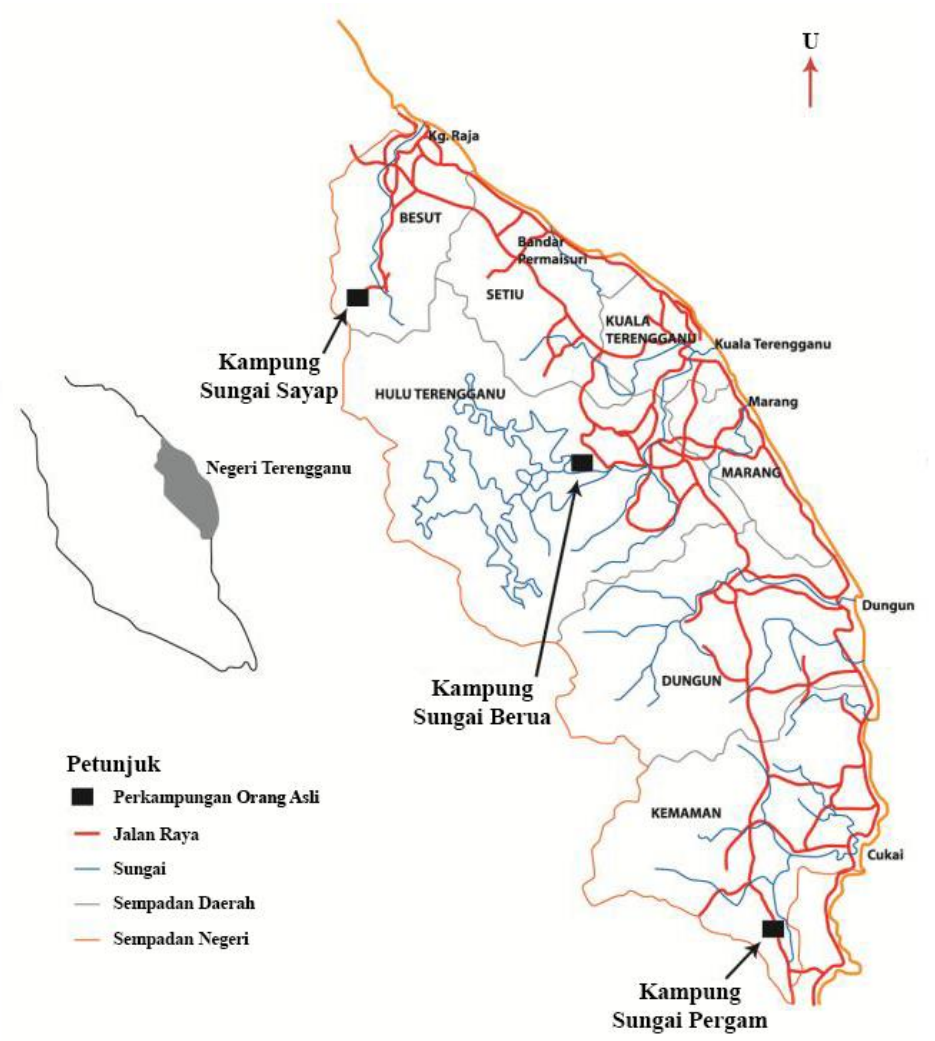

Figure 1. Distribution of Orang Asli Village in Terengganu (Ramle, 2001)

Informants are determined according to purposive sampling. Through this method, informants are chose based on certain characteristics only. The informants will be chose in the community of Semaq Beri in Kampung Sungai Berua. Informants are also select from the head of household and experienced individuals in Kampung Sungai Berua. The focus of the informants is that of those who have been or still participate in the economic development program implemented by the implementers of development. Although, the purposive sampling principle is said to be biased because informants are chosen according to the wishes of the researcher but are in line with the need for research findings. According to Reinard (2001), researchers need to use their own judgment to select respondents who are most suited to their studies.

The data are collect through several data collection techniques. Among the collecting techniques used were document study, observation, interviews and focus group discussion. Focus group discussion is a method used by researchers to collect data quickly and easily from some informants at the same time, this method also requires interaction within the informal group (Edmunds, 2000). Document study is one of the methods to get relevant information about the issues and problems studied through secondary sources. According to Kamarul Azmi (2012), documents are the easiest secondary source for researchers as required information is already available and it is difficult to be deceived. Data collection is simplified, researchers use audio and video recordings. This expedites the existing data collection process. 


\section{RESULTS}

The findings from the study have shown that the majority of them are still conducting traditional economic activities. This has resulted in the involvement of the Semaq Beri tribe in Hulu Terengganu to the economic development program still low. Due to focusing on traditional economic activities, participants of the economic development program did not fully commit to the development program they have been involved with. This has caused the objective of the economic development program to be unsuccessful and some of the implemented programs have failed. The researcher found that there several factors that cause participants' involvement to be low and why they cannot put more contribution to the economic development program. The factors are :

\section{i. Education}

Studies show that the majority of Kampung Sungai Berua residents have a low level of educational attainment. The majority of household heads only have primary school level education, they do not pursue higher education. It has given negative impact of their participation into the economic development program. Because of their low level of education, they are not capable to participate on economic activities that require them to use modern equipment or technology. Modern occupations that require high levels of academic achievement are also unacceptable to them due to educational level constraints.

\section{ii. Dependence on Forests}

From the aspect of cultural beliefs, they have a strong hold on their culture. This has resulted in almost all their deeds being closely relate to the culture that has been practice for thousands of years. One of the cultures that has led to a lack of involvement in the economic development program is the high dependence on forests. For Semaq Beri tribes, forests are a special gift of supernatural power for the enjoyment of human life. As the forests have a diverse range of resources, forest has become important as it serves as a basis for various commercial activities that are also done commercially (Ramle, 2014).

Dependence on forests involves forest as a source of food and forests as a source of income. They will go to the jungle to search for edible forest resources, so they will hunt animals and find fruits to eat. From the aspect of the forest as a source of income, they will find and collect timber, rattan and herbs for sale to buyers (Ramle, 2014).

The sale of forest products has generated their income. The effect is that they are more focus traditional economic activities than modern economic activities introduced by JAKOA. Among the opportunities of modern economic activity introduced are agricultural programs and opportunities to work in oil palm estates. However, for them the income derived from these modern economic activities is not comparable to the income derived from traditional economic activity. For agricultural programs, they point out that income from agricultural programs takes a long time because they have to wait two or three months for crop production. Even though they have planted crops in the orchard, however, after some period they will return to the activity of collecting forest products because of the need for faster financial resources. 


\section{iii. Location and Settlement}

The location of the Semaq Beri tribal settlements is quite far in the interior. Despite having a good road, it is still far from the nearest town of Kuala Berang. This makes it difficult for them to access the services and facilities available in the city. Being in the interior has reduced and restricted their job opportunities. Indirectly, they focus only on economic activities on traditional economic activities, as there is no modern employment opportunity if they want it.

From the geographical point of their settlements, their settlements are hilly areas. Their settlements do not have a flat land area. The lack of flat land area has caused many problems to the development program. Among them is JAKOA does not have enough flat area to open palm oil plantations that can generate Orang Asli income. The residents of Kampung Sungai Berua who want to open their own plantations also face problems due to the lack of flat areas for them to start agriculture.

\section{iv. Top-Down Development Program}

One of the lack of involvement to modern economic activity is due development program is characterized as top-down development program. This top-down development did not getting high involvement, the contribution of the workforce will be low and the commitment given is not fully. This is because the top-down development program is a guide to participants. In the Semaq Beri community at Kampung Sungai Berua there are those who do not like to work through the instructions. To gain more participation different type of approach need to be take. Davies et al (2004) stated to gain participation among community, the community need to be involve by their cooperation not by instruction given to them. This will create bottom-up type of development program rather than top-down development program.

v. Lack of Staff and Monitoring

JAKOA has tried its best in implementing economic development programs. However, they also face problems in implementing them. Among the problems faced by JAKOA in Terengganu is the lack of staffing and the lack of time to monitor. From the interviews and observations of JAKOA Terengganu staff are very few. They are also burden with various work arrangements. As a result, they have no time to go to development program site in the village. No monitoring has caused the participants not to do their job well. In fact, no monitoring has caused interest and motivation of participants to decrease. Eventually they will return to their traditional economic activities due to lack of monitoring.

\section{CONCLUSION}

In conclusion, several factors cause community involvement in the development program to be low. From this study, researcher found that education, forest dependency, location and geography, topdown development program and lack of staff and monitoring resulted in the involvement in Semaq Beri Hulu Terengganu tribe is still low. Indirectly it has resulted in failure to some of the economic development programs that have been implement. To solve this problem, some actions need to be taken by JAKOA and the Orang Asli community themselves. Both groups need to work together to find the best solution. Among the recommendations for improvement is to increase the amount of payments to Orang Asli participation in the economic development program, obtain the views of 
the Orang Asli before an economic development program is implement and increase their motivation and interest in modern work.

Among the contributions from this study are studies have identified problems that occurred among the Orang Asli on their involvement in the economic development program. Of the problems, this research has also found there are some suggestions for improvement. JAKOA as a development executive can use these proposed improvements for future economic development programs. Through these proposed improvements, it is hoped that the involvement of the Orang Asli will continue to increase and thus will succeed in implementing the economic development program.

\section{Acknowledgement}

This research is part and funded by Fundamental Research Grant Scheme (FRGS) 'Membentuk Model Pemerkasaan Pendidikan Masyarakat Orang Asli di Malaysia'. References number FRGS/1/2017/SS109/UNISZA/01/1.

\section{References}

Asnarulkhadi. A. S. (2005). Pendayaupayaan Komuniti Melalui Penglibatan: Satu Penilaian Umum Terhadap Pembangunan Komuniti di Malaysia. Malaysian Journal of Social Policy and Society, Vol. 2. Institut Sosial Malaysia.

Davies, B., Blackstock. K., Brown. K. \& Shannon. P. (2004). Challenges in Creating Local Agrienvironmental Cooperation Action Amongst Farmers and Other Stakeholders. The Macaulay Institute, Aberdeen

Edmunds, H. (2000). The Focus Group Research Handbook. Thousand Oaks, CA. Sage

Jabatan Kemajuan Orang Asli. (2011). Pelan Strategik Kemajuan Orang Asli 2011 - 2015. Bahagian Perancangan dan Penyelidikan, Jabatan Kemajuan Orang Asli. Kuala Lumpur.

Kamarul, A. (2012). Metodologi Pengumpulan Data dalam Penyelidikan Kualitatif. Paper Presented in Kursus Penyelidikan Siri 1 2012. Organized Institut Pendidikan Guru Malayia. 28 - 29 Mac.

Moleong, Lexy J. (2007). Metodologi Penelitian Kualitatif. Penerbit PT Remaja Rosdakarya Offset, Bandung

Nicholas, C. (1998). The Orang Asli in the Malaysian nation state: The Politics and Development of Marginal Indigenous Communities. Ph.D.thesis.University of Malaya.

Ramle, A dan Abdul, R. A. (2007). Peranan Jabatan Hal Ehwal Orang Asli Dalam Pembangunan Orang Asli Terengganu. Dalam Mohd Zahedi Daud et al. (Edit). Orang Asli Negeri Terengganu: Warisan dan Pembangunan. Kuala Terengganu: Universiti Darul Iman Malaysia.

Ramle, A. (1993). Semaq Beri: Komuniti Orang Asli di Terengganu. Kuala Terengganu: Kolej Agama Sultan Zainal Abidin.

Ramle, A. (2001). Peralihan ekonomi masyarakat Orang Asli Terengganu: Satu sudut ekonomi persekitaran. Tesis Dr. Falsafah. Universiti Sains Malaysia.

Ramle, A. (2008). Orang Asli dalam Arus Pembangunan Nasional di Terengganu. In Ma'rof Redzuan \& Sarjit S. Gill (Eds.), Orang Asli; Isu, Transformasi dan Cabaran (pp. 46). Serdang: Universiti Putra Malaysia.

Ramle, A. (2014). Orang Asli Pembangunan dan Transformasi. Universiti Sultan Zainal Abidin. Terengganu. 
Reinard, J. (2001). Introduction to Communication Research (3rd ed.). New York: McGraw Hill.

Zainal, A. (2004). Jabatan Hal Ehwal Orang Asli: Peranan dalam bidang penyelidikan. Paper Presented in Seminar Sehari Tradisi Lisan Masyarakat Orang Asli. Organized by Pusat Pengajian Bahasa, Kesusasteraan and Kebudayaan Melayu. Fakulti Sains Sosial dan Kemanusian, Universiti Kebangsaan Malaysia. 8 September.

\section{Corresponding Author}

Hafis Simin,

Faculty of Applied Social Sciences, Universiti Sultan Zainal Abidin, Malaysia.

Email: mohamadhafis@unisza.edu.my 